\title{
A STUDY OF PLASMA POTASSIUM AND ELECTROCARDIOGRAPHIC CHANGES AFTER A SINGLE DOSE OF SUCCINYLCHOLINE*
}

\author{
William Evers, M.D., Gabor B. Racz, M.B., And Allen B. Dobkin, M.D.
}

The CuRnent CONTRoversy regarding the role of succinylcholine in producing cardiovascular disturbances deserves the careful attention of every anaesthesiologist. These changes, which may be catastrophic in nature, can occur after a single intravenous dose $\mathrm{e}^{1-3}$ as well as following repeated administrations. ${ }^{4-9}$ The disturbances range from mild, transient changes in rate or rhythm through severe bradycardia and serious arrhythmias to cardiac arrest.

Several theories have been offered to explain the causes, but none of them seems adequate. One of the most recent concerns the increase of plasma potassium immediately following the intravenous administration of succinylcholine.

The release of plasma potassium as a result of damage to myofibrillae has been described. The occurrence of haemoglobinuria or myoglobinaemia after vigorous muscular exercises like forced marches, karate, ${ }_{2}^{10}$ or football ${ }^{11,12}$ has been well documented, and several authors have described myoglobinaemia or myoglobinuria after the administration of succinylcholine. ${ }^{13-15}$ A case of acute renal failure following the use of succinylcholine in a patient with idiopathic myoglobinuria was described by Bennike. ${ }^{14}$ These phenomena (myoglobinuria, myoglobinaemia) after succinylcholine indicate myofibrillar damage and presumably the release of intracellular potassium.

This study was designed to determine the incidence, magnitude and timing of plasma potassium changes and their correlation with electrocardiographic abnormalities following the administration of succinylcholine.

\section{Materials AND Methods}

One hundred anaesthetics were studied in patients undergoing surgical procedures requiring only a single, short period of muscular relaxation and no endotracheal intubation. The reason for avoiding patients in whom intubation or other forms of pharyngeal or laryngeal manipulation would become necessary was to eliminate the likelihood of electrocardiographic abnormalities that frequently accompany such events.

Eighty-nine of the one hundred patients studied were females, most of whom were undergoing vaginal gynaecological procedures; ten male patients were operated on for relatively minor orthopedic or urological problems, and one for debridement of burns. From the point of view of anaesthetic risk, the patients seemed to represent a fair sample of the usual surgical material and age groups

"From the Department of Anesthesiology, State University Hospital, State University of New York, Upstate Medical Center, Syracuse, New York. This study was supported by a grant-in-aid by Dr, W. P. Colvin of Burroughs Wellcome \& Company, Tuckahoe, New York. 
(see Table I). Most of the patients listed as ASA II were so classified because of obesity. Four patients in this series had repeated anaesthetics for the same procedure (radium implantation) at seven- to thirty-day intervals.

Premedication consisted of atropine $(0.4$ to $0.6 \mathrm{mg}$ ) alone or with meperidine, pentobarbital, or hydroxyzine (see Table II). The electrocardiogram was monitored beginning with the preinduction period. Anaesthesia was induced with thiopental, after which nitrous-oxide-oxygen $(6: 4 \mathrm{~L} / \mathrm{min})$ and halothane $(0.3$ to $1.0 \%$ ) were used for maintenance.

TABLE I

ASA Risk Grouping

\begin{tabular}{lccccc}
\hline \hline & & \multicolumn{4}{c}{ Reason for risk assignment } \\
\cline { 3 - 6 } $\begin{array}{l}\text { ASA } \\
\text { risk }\end{array}$ & $\begin{array}{c}\text { Total no. } \\
\text { of patients }\end{array}$ & obesity & $\begin{array}{c}\text { cardiovascular } \\
\text { disease }\end{array}$ & diabetes & other \\
\hline I & 63 & - & - & - & - \\
II & 34 & 20 & 9 & 3 & 2 \\
III & 3 & 1 & 1 & - & 1 \\
& & & & & (burns) \\
\hline
\end{tabular}

TABLE II

Premedication

(no. of patients)

\begin{tabular}{cccc}
\hline \hline Atropine & $\begin{array}{c}\text { Atropine } \\
\text { meperidine }\end{array}$ & $\begin{array}{c}\text { Atropine } \\
\text { pentobarbital }\end{array}$ & $\begin{array}{c}\text { Atropine } \\
\text { hydroxyzine }\end{array}$ \\
\hline 11 & 67 & 18 & 4 \\
\hline
\end{tabular}

The samples for potassium determinations were taken from a 21-gauge scalpvein needle set (Abbott "butterfly") that was introduced into the antecubital vein of the arm opposite to the one used for very slow infusion of 5 per cent dextrose in water and for the administration of drugs. A blood sample was taken for plasma potassium immediately prior to the intravenous injection of a bolus of succinylcholine $1.5 \mathrm{mg} / \mathrm{kg}$. ( $2 \%$ solution).

As soon as fasciculation became apparent, another $3 \mathrm{ml}$ blood sample was drawn, and then further samples every 15 seconds for 2 minutes, every minute for 5 minutes, and then at 10 and 15 minutes after the administration of succinylcholine.

Plasma potassium was determined using a Coleman Flame Photometer. The laboratory error for the method used is $\pm 0.1 \mathrm{mEq} / \mathrm{L}$. The electrocardiogram (lead 2) was monitored by a Sanborn direct-writing electrocardiograph.

\section{RESULTS}

As can be seen from Table III, we attempted to analyse four ranges of increase in plasma potassium in order to facilitate their correlation with any electrocardiographic changes that occurred. 
EVERS et al.: PLASMA POTASSIUM AND ECG CHANGES AFTER SUCCINYLCHOLINE 275

TABLE III

Range of Plasma Potassium Changes

(no. of patients)

\begin{tabular}{ccccc}
\hline \hline $\begin{array}{c}\text { Less than } \\
0.4\end{array}$ & $\begin{array}{c}0.4-0.6 \\
\mathrm{mEq} / \mathrm{L}\end{array}$ & $\begin{array}{c}0.6-0.8 \\
\mathrm{mEq} / \mathrm{L}\end{array}$ & $\begin{array}{c}0.8-1.0 \\
\mathrm{mEq} / \mathrm{L}\end{array}$ & $\begin{array}{c}\text { Over } \\
1.0 \\
\mathrm{mEq} / \mathrm{L}\end{array}$ \\
\hline 40 & 39 & 16 & 3 & 2 \\
\hline
\end{tabular}

Only five patients showed an increase in potassium levels over $0.8 \mathrm{mEq} / \mathrm{L}$, a magnitude that could by itself produce electrocardiographic changes. ${ }^{16}$ In 55 patients, potassium levels showed increases between 0.4 and $0.8 \mathrm{mEq} / \mathrm{L}$, a range that is much less likely to alter cardiac rate or rhythm. Forty patients had potassium changes of less than $0.4 \mathrm{mEq} / \mathrm{L}$.

The timing of the peak in potassium levels was not uniform, and there was no correlation in either timing or magnitude between the changes in the electrocardiogram and those in potassium levels (see Table IV). In some patients, the peak plasma potassium levels were reached within 90 to 120 seconds; in others, well after 5 minutes.

TABLE IV

Relationship between Potassium Levels and ECG Changes

\begin{tabular}{lccc}
\hline $\begin{array}{c}\text { Range of } \\
\text { potassium } \\
\text { changes }\end{array}$ & $\begin{array}{c}\text { Number } \\
\text { of } \\
\text { patients }\end{array}$ & $\begin{array}{c}\text { No. of ECG changes } \\
\text { typical for } \\
\text { potassium excess }\end{array}$ & $\begin{array}{c}\text { ECG changes usually } \\
\text { associated with } \\
\text { succinylcholine } \\
\text { (see Table } \mathrm{V} \text { ) }\end{array}$ \\
\hline $\begin{array}{l}0.4-0.6 \\
\mathrm{mEq} / \mathrm{L}\end{array}$ & 39 & 4 & 6 \\
$\begin{array}{l}0.6-0.8 \\
\mathrm{mEq} / \mathrm{L}\end{array}$ & 16 & 4 & 6 \\
$\begin{array}{c}0.8-1.0 \\
\mathrm{mEq} / \mathrm{L}\end{array}$ & 3 & 1 & 1 \\
$\begin{array}{c}\text { Over } 1.0 \\
\mathrm{mEq} / \mathrm{L} .\end{array}$ & 2 & - & 1 \\
\hline
\end{tabular}

TABLE V

INCIDENCE OF ECG ChANGES

Attributable to Intravenous Administration OF SUCCINYLCHOLINE

\begin{tabular}{ll}
\hline \multicolumn{1}{c}{ (no. of patients) } \\
\hline Tachycardia & 5 \\
Bradycardia & 6 \\
Increased A-v & 1 \\
conduction time & 3 \\
PVC & \\
\hline
\end{tabular}

Electrocardiographic changes usually attributed to the intravenous injection of succinylcholine ( Table V) were encountered in 15 patients. In none of them was 
there any clinical evidence of changes in circulatory dynamics, and only seven had changes in plasma potassium exceeding $0.6 \mathrm{mEq} / \mathrm{L}$.

The influence of digitalis ${ }^{\mathbf{1 7}}$ on the incidence of electrocardiographic abnormalities after succinylcholine could be seen in two of the five patients who were digitalized. In one patient the electrocardiogram showed a decrease in voltage, bradycardia, and premature ventricular contractions. Another patient had inverted T-waves and bigeminal rhythm. In both cases, these abnormalities disappeared within a few minutes. No clinical signs indicating sudden circulatory changes were detected in either of these instances.

The four patients who had two anaesthetics each, conducted according to the outlined method, did not show any variations from one procedure to the other. One of them developed tachycardia after each administration of succinylcholine, but the changes of plasma potassium levels were insignificant.

\section{Discussion}

The involvement of intravenous succinylcholine in producing undesirable and even grave cardiovascular changes has been pointed out by many workers. The reasons given for such effects, however, vary greatly from author to author, and several hypotheses have been developed according to experience and patient material. Anaphylaxis to succinylcholine has been described in eight patients. ${ }^{18,10}$ Thompson, ${ }^{20}$ working with dogs, found elevated serum histamine levels after the injection of succinylcholine. Sensitivity to succinylcholine, whether genetic ${ }^{21}$ or acquired, has been mentioned as a reason for the cardiovascular effects produced. ${ }^{6,22,23}$

Others have suspected the involvement of the autonomic nervous system: since succinylcholine is very similar in chemical structure to acetylcholine (Ach.), it is believed to mimic the effects of the latter not only at the myoneural junction ${ }^{24}$ but also at other sites. ${ }^{22,25,26}$ This becomes especially true as levels of acetylcholine may increase with the accumulation of succinylcholine breakdown products after repeated doses of the drug. ${ }^{27}$ Several authors suggest that succinylcholine can produce both muscarinic and nicotinic effects. ${ }^{28-31}$ These succinylcholine-produced variations in the vagal and sympathetic tone may be responsible for the ensuing arrhythmias and blood pressure changes. ${ }^{32}$ A direct vagal-stimulating effect (nucleus dorsalis) has also been postulated. ${ }^{7,31,33,34}$

Direct myocardial-depressing effects of succinylcholine have been found by Galindo and Gologorski. ${ }^{7,31,35}$ Gologorski ${ }^{31}$ also noticed that succinylcholine lowers the irritability threshold of the myocardium.

The outstanding group of patients in whom succinylcholine seemed to have been responsible for serious circulatory complications were those who had received extensive burns; most of them had survived the immediate post-burn shock and had entered the so-called "danger period" in recovery (third to ninth week). ${ }^{1,2,36}$ Many reports of cardiac arrest in burned patients after the administration of succinylcholine seem to have one common factor: the catastrophe happened during or immediately following endotracheal intubation or attempts at it. ${ }^{1,2,36}$ Several explanations for this coincidence can easily be put forward: 
most of the burned patients were in the so-called "toxic stage," when low-grade sepsis, myocarditis, fever, and acidosis are quite common.,36-41 Plasma and true cholinesterase levels are frequently depressed, ${ }^{42}$ and this, in turn, is likely to increase vagal tonus. Endotracheal intubation or laryngeal manipulation are known to produce arrhythmias ${ }^{2,3,36,37,43-45}$ in lightly anaesthetized patients.

Administration of succinylcholine to such patients produces a marked rise in plasma potassium as well as increased vagotonicity; ${ }^{36,42}$ it can thus be easily imagined that the combination of all the pre-existing factors plus a sudden rise in plasma potassium levels as well as laryngeal manipulation in the presence of mild hypoxia and hypercarbia may produce a sudden circulatory collapse.,40,46

Serious arrhythmias and death after the use of succinylcholine $e^{2,37,40,46}$ have been reported since $1961 .^{40,46}$ Recently, many other such incidents have been reported, leading one of the authors to "studiously" avoid succinylcholine in the burned patient. ${ }^{38}$

In addition to the burned patient, one with major tissue trauma also seems to carry a high risk of circulatory collapse concomitant with high potassium levels after succinylcholine administration. ${ }^{3}$

Potassium is also released as a result of changes in cellular permeability during depolarization, ${ }^{24,47-50}$ or owing to the acetylcholine-like effects of succinylcholine, ${ }^{8,51}$ by increasing the flux of potassium from intracellular to extracellular space, and it is this rapid change in the relation between intracellular and extracellular potassium $\left(\mathrm{K}_{\mathrm{I}} / \mathrm{K}_{\mathrm{O}}\right)$ that, together with alterations in cellular electrical potential, may lead to arrhythmias. ${ }^{16,51,52}$

In the laboratory, stimulation of isolated muscles has been shown to be accompanied by a considerable loss of potassium. ${ }^{53-55}$ On the other hand, Epstein ${ }^{56}$ (403 anaesthetics) and Lowenstein ${ }^{38}$ ( 406 anaesthetics) do not share the view that succinylcholine is to be incriminated in cardiovascular collapse in the anaesthetized patient. They suggest hypovolemia, acidosis, and hypoxia as the main responsible factors.

Although the increase in plasma potassium after the administration of succinylcholine appears to be an undisputed fact, its importance as well as its magnitude still remains a subject of heated debate. High levels of potassium depress idioventricular automaticity ( $\mathrm{A}-\mathrm{v}$ block) and intraventricular conduction. ${ }^{57}$ They may also produce ectopic ventricular centres, especially if the formation of impulses from the primary pacemaker becomes slower and irregular. ${ }^{58}$ It is the rate of change in potassium levels rather than the absolute value (except in extreme cases) that is responsible for the sudden appearance of electrocardiographic abnormalities and circulatory changes. ${ }^{16}$

That considerable hyperkalaemia may be present with only minor circulatory changes has been demonstrated by Maxwell, Chamberlain, Smith, and Surawicz. ${ }^{59-64}$ It was also reported that a rise in plasma potassium actually inhibits the disturbances in $\mathrm{A}-\mathrm{V}$ conduction caused by acetylcholine or vagal stimulation. ${ }^{65-67}$

Our findings indicate that the acute plasma potassium changes after a single intravenous dose of succinylcholine in the average-risk patient are of a magnitude rarely sufficient to produce significant circulatory changes. The majority of the 
reported serious or fatal accidents following the use of succinylcholine occurred at the time of laryngeal manipulation or immediately thereafter. The patients exhibiting such exaggerated reactions had either severe burns, ${ }^{1,2,36,42}$ extensive tissue trauma, ${ }^{3}$ or a protracted debilitating illness. ${ }^{68}$

It appears that potassium changes by themselves are probably not to be blamed for the cardiovascular catastrophies after succinylcholine. ${ }^{60,64}$ Other factors such as the direct influence of succinylcholine on the myocardium and autonomic activity should be considered. Although the exact mechanism is not yet known, it is quite possible that, in the presence of severe trauma, acidosis, toxaemia, hypoxia, and marginal electrolyte balance, superimposed upon strong reflex stimulation (endoscopy, intubation), even relatively small plasma potassium alterations will set the stage for major circulatory disturbances.

\section{SUMMARY}

Electrocardiographic monitoring and serial plasma potassium determinations before, during, and after intravenous succinylcholine were performed for 100 clinical anaesthetics. We found that the appearance and magnitude of plasma potassium changes had no temporal relationship to the observed transient electrocardiographic abnormalities. In no instance did appreciable circulatory changes take place.

\section{RÉSUMÉ}

Au cours de 100 anesthésies consécutives, nous avons présenté une étude des changements électrocardiographiques ainsi que des modifications du taux de potassium sérique à la suite d'une injection de $1.5 \mathrm{mg} / \mathrm{kg}$ de succinylcholine. Chez ces malades, nous n'avions besoin que d'un bref instant de relâchement musculaire. Nous avons observé des modifications du taux de potassium sérique mais il nous a été impossible d'établir une relation concomittante entre les anomalies électrocardiographiques et lapparition des modifications du taux de potassium et l'importance de ces modifications. Les anomalies électrocardiographiques observées ont été, d'ailleurs, très passagères. Nous n'avons pas observé de troubles circulatoires importants.

\section{REFERENCES}

1. Belin, R. P. \& Karleren, C. I. Cardiac Arrest in the Burmed Patient Following Succinylcholine Administration. Anesthesiology. 27: 516 (1966).

2. Benway, R. E.; Maier, E. S.; \& JeniceK, J. A. Anesthetic Management of Severely Burned Patient. Am. J. Surg. 103: 677 (1962).

3. Houston, J. B. Serum Potassium Changes Following Succinylcholine. Personal communication (to be published).

4. Meyer, E. \& Huegin, W. Cardiovascular Reactions to Succinylcholine. Anaesthesist. 12: 65 (1963).

5. Bullouch, J. Intermittent Suxamethonium Injections. Brit. Med. J. 5124: 786 (1959).

6. Pedinelli, L.; Malavaud, A.; \& Golnard. P. Arrét cardiaque par Succinyl-choline, réanimé avec succès par massage trans-diaphagmatique, Lyon Chir. 61: 776-778 (1965). 
7. Gologorskr, V. A. \& Umanov, I. M. Studies of the Effect of Succinylcholine on Cardiac Activity. III Symposium Internationale Anaesthesiologiae (1967), pp. 120-21.

8. Williams, C. H.; Deutsch, S.; Linde, H. W.; Bullough, J. W.; \& Dhupps, R. D. Effects of Intravenously Administered Succinylcholine on Cardiac Rate, Rhythm and Arterial Blood Pressure in Anesthetized Man. Anesthesiology. 22: 947 (1961).

9. Williams, R. T. Electrocardiographic Changes Following Repeated Injections of Decamethonium and Subsequent Injections of Succinylcholine. Canad. Anaesth. Soc. J. 9: 263 (1962).

10. Streeton, J. A. Traumatic Haemoglobinuria Caused by Karate Exercises. Lancet. 2: 191 (1967).

11. Eliot, R. S.; Shafer, R. B. \& Gibas, M. A. Demonstration of Myoglobinemia in Football Players. Arch. Phys. Med. 48: 229 (1967).

12. Kılburn, K. H. Muscular Origin of Elevated Plasma Potassium during Exercise. J. Appl. Physiol. 21: 675 (1966).

13. Airaksinen, M. M. \& TamMisto, T. Myoglobinuria after Intermittent Administration of Succinylcholine during Halothane Anesthesia. Clin. Pharmac, and Therap. 7: 583 (1967).

14. BenNIKE, K. A. \& JARnum, S. Myoglobinuria with Acute Renal Failure Possibly Induced by Suxamethonium. Brit. J. Anaesth. 36: 730 (1964).

15. Tammisto, T. \& AIRAkSinen, M. M. Suxamethonium-induced Myoglobinuria. Brit. J. Anaesth. 37: 464 (1965).

16. Dowdy, E. G. \& FABIAN, L. W. Ventricular Arrhythmias Induced by Succinylcholine in Digitalized Patients. Anesth. \& Analg. 42: 501 (1963).

17. Jerums, G.; Whittingham, S.; \& Wilson, P. Anaphylaxis to Suxamethonium: A Case Report. Brit. J. Anaesth. 39: 73 (1967).

18. Smirt, N. L. Histamine Release by Suxamethonium. Anaesthesia. 12: 293 (1957).

19. Thоmpson, W. L. \& Walton, R. P. Evaluation of Plasma Histamine Levels in Dogs Following Administration of Muscle Relaxants, Opiates and Macromolecular Polymers. J. Pharmacol. \& Exper. Therap. 143: 131 (1964).

20. HALL, L. W. Unusual Reaction to Suxamethonium Chloride. Brit. Med. J. 2: 1305 (1966).

21. Schoenstadt, D. A. \& Whitcher, C. E. Observations on the Mechanism of Succinylcholine-Induced Cardiac Arrhythmias. Anesthesiology. 24: 358 (1963).

22. Takafashi, K. Mechanism of Succinylcholine-Induced Arrhythmia. Jap. J. Anesth. 14: $942(1965)$.

23. Kitz, R. J. The Physiology and Pharmacology of Muscle Relaxants. Anesthesia Rounds. (Ayerst Lab.) 1: no. 2 (1967).

24. Johnstone, M. Relaxants and the Human Cardiovascular System. Anaesthesia 10: 122 (1955).

25. Clinical Anesthesia Conference. Bradycardia after Succinylcholine. New York J. Med. 66: 874 (1966).

26. Leigh, M. D.; MCCAy, D. D.; BeLton, M. K.; \& Lewis, G. B. Bradycardia Following Intravenous Administration of Succinylcholine Chloride to Infants and Children. Anesthesiology. 18: 698 (1957).

27. Adams, A. K. \& Hall, L. W. An Experimental Study of the Action of Suxamethonium on the Circulatory System. Brit. J. Anaesth. 34: 445 (1962).

28. Aubercer, H. Ueber einen Anesthesietodesfall bei einem Kind während der Narkoseeinleitung. Anaesthesist. 14: 158 (1965).

29. Berternvide, K. V. Action of Succinylcholine Chloride on Circulation. Brit. J. Pharmacol. 10: 265 (1955).

30. Gologonski, V. A. \& Umanov, I. M. Influence of Listenon on Cardiac Action. Vestn. Khir. 7: 102 (1965).

31. HofFman, B. F. Autonomic Control of Cardiac Rhythm. Bull. N.Y. Acad. Med. 43: 1087 (1967).

32. ANDREUCCI, S. Succinylcholine: Considerations on a Neurovegetative Effect Following the Injection of Successive Doses. Minerva Anest. 28: 385 (1962).

33. Lupprian, K. G. \& Churchitl-Davidson, H. C. Effect of Suxamethonium on Cardiac Rhythm. Brit. Med. J. 2: 1774 (1960).

34. Galindo, A. H. \& Davis, T. B. Succinylcholine and Cardiac Excitability. Anesthesiology. 23: 32 (1962).

35. Bush, G. H.; Graham, H. A. P.; Littlewood, A. H. M.; \& Scott, L. B. Danger of 
Suxamethonium and Indotracheal Intubation in Anaesthesia for Burns. Brit. Med. J. 5312: 1081 (1962).

36. McCaughey, T. J. Burn Mortality and the Anaesthetist. Canad. Anaesth. Soc. J. 10: 501 (1963).

37. McCaughey, T. J. Hazards of Anaesthesia for the Burned Child. Canad. Anaesth. Soc. J. 9: $220(1962)$.

38. Lowenstein, E. Succinylcholine Administration in the Burned Patient. Anesthesiology. 27: 494 (1966).

39. Allan, C. M.; Cullen, W. G.; \& Grllies, D. N. M. Ventricular Fibrillation in a Burned Boy. C.M.A.J. 85: 432 (1961)

40. Ieni, R.; Noveld, G. P.; \& Palumbo, D. So-called Bradycardia Due to Succinylcholine. Minerva Anest. 31: 20 (1965).

41. Bush, G. H. The Use of Muscle Relaxants in Burnt Children. Anaesthesia. 19: 231 (1964).

42. Akdiknen, S. A.; Boba, A.; Landmesser, C. M. Reappraisal of Incidence of Ventricular Arrhythmias Following Succinylcholine Administration. New York State J. Med. 65: 2902 (1965).

43. Evers, W. Reflex Changes in Heart Rate and Rhythm during Laryngeal Manipulation. Thesis, Graduate School, University of Minnesota (1954).

44. Kuner, J.; Enescu, V.; Utsu, F.; Boszormenyi, E.; Bernstein, H.; \& Corday, E. Cardiac Arrhythmias during Anesthesia. Dis. Chest. 52: 580 (1967).

45. Finen, B. L. \& Nylen, B. O. Cardiac Arrest in the Treatment of Burns and Report on Hypnosis as a Substitute for Anesthesia. Plastic and Reconstr. Surg. 27: 49 (1961).

46. Klupp, H.; Kraupp, O.; Honetz, N.; Kobingen, W.; \& Loudon, M. Ueber die Freisetzung von Kalium aus der Muskulatur unter Einwirkung einiger Muskelrelaxanten. Arch. Internat. Pharmacodyn. 98: 340 (1954).

47. List, W. F. Serum Potassium Changes during Induction of Anaesthesia. Brit. J. Anaesth. 39: 480 (1967).

48. Stevenson, D. E. Changes in the Blood Electrolytes of Anaesthetized Dogs Caused by Suxamethonium. Brit. J. Anaes. 32: 364 (1960).

49. Sunzhian, A. B. Influence of Depolarizing Relaxants (Ditiline) on Electrolyte Content of Blood Serum in Dogs. Eksp. Khir. Anest. 9: 80 (1964).

50. Holland, W. C.; Klein, R. L.; \& Buggs, A. H. Factors Affecting Action of Acetylcholine on Transmembrane Flux of Potassium in Isolated Atria. Am. J. Physiol. 196: 478 (1959).

51. Sliom, C. M. Postoperative Respiratory Inadequacy Following Suxamethonium and Tetrahydroaminoacrine. Anaesthesia. 21: 223 (1966).

52. Surawicz, B. Personal communication.

53. Paton, W. D. M. Mode of Action of Neuromuscular Blocking Agents. Brit. J. Anaesth. 28: $470(1956)$.

54. Woon, E. H.; Collnss, D. A.; \& MoE, G. K. Potassium Exchanges between Mammalian Muscle and Blood in Relation to Activity. Amer. J. Physiol. 126: 657 (1939).

55. Zaimis, E. J. Transmission and Block of the Motor Endplate and in Autonomic Ganglia. Pharmacol. Rev. 6: 53 ( 1954 ).

56. Epstein, B. S.; Rudman, H. L.; Harwy, D. L.; \& Downes, H. Comparison of Orotracheal Intubation with Tracheostomy for Anesthesia in Patients with Face and Neck Burns. Anesth. \& Anal. 45: 352 (1966).

57. Vassale, M.; Greenspan, K.; Jomain, S.; \& Hoffman, B. F. Effects of Potassium on Automaticity and Conduction of Canine Hearts. Am. J. Physiol. 207: 334 (1964).

58. Pick, A. Arrhythmias and Potassium in Man. Am. Heart J. 72: 295 (1966).

59. Maxwell, G. M. Effects of Hyperkalaemia upon the General and Coronary Haemodynamics of the Dog. Aust. J. Exper. Biol. Med. Sc. 43: 657 (1965).

60. Chamberlain, M. J. Emergency Treatment of Hyperkalaemia. Lancet. 1: 464 (1964).

61. Smirh, N. T. The Hemodynamic Effects of Potassium Infusion in Dogs. Anesthesiology. 26: 633 (1965).

62. Surawicz, B. Electrolytes and the ECG. Am. I. Cardiol. 12: 656 (1963).

63. Surawicz, B. Arrhythmias and Electrolyte Disturbances. Bull. New York Acad. Med. 43: 1160 (1967)

64. Surawicz, B. Hemodynamic and Electrocardiographic Effects of Hyperpotassemia: Differences in Response to Slow and Rapid Increases in Concentration of Plasma Potassium. Am. Heart J. 73: 647 (1967). 
EVERS et al.: PLASMA POTASSIUM AND ECG CHANGES AFTER SUCCINYLCHOLINE 281

65. Fisch, C.; Feicenbaum, H.; \& Bowers, J. A. The Inhibition of Acetylcholine-Induced Atrioventricular Block by Potassium. J. Clin. Invest. 42: 563 (1963).

66. Fisch, C.; Knoebed, S. B.; \& Feigendaum, H. The Effects of Acetylcholine and Potassium on Repolarization of the Heart. J. Clin. Invest. 43: 1769 (1964).

67. Fisch, C.; Greenspan, K.; \& Edmunds, R. E. Complete Atrioventricular Block Due to Potassium. Circ. Res. 19: 373 (1966).

68. Greenspan, K.; Wunsch, C. M.; \& Fisch, C. Relationship between Potassium and Vagal Action on Atrioventricular Transmission. Circ. Res. 17: 39 (1965).

69. Palazzondruano, M.; Raineri, A.; Battaglia, A.; \& Barone, G. Influenza del potassio sugli effetti elettrocardiografici indotti dall'acetilcolina. Min. Cardioangiologica. 13: 581 (1965).

70. Thomas, E. T. Personal communication. 